\title{
Returns for Education in Kosovo: Estimates of Wage and Employment Premia
}

Avdullah Hoti *

Abstract:

This paper provides an analysis of the returns for education in Kosovo using data from a Household and Labour Force Survey. We argue that given the high unemployment rate in Kosovo, employed individuals may not be randomly selected from the labour force. Therefore, the estimates of the rates of returns for education based on the standard Mincerian earnings function may be biased downwards. Hence, the Heckman sample selection model is implemented, which adjusts the estimates of the wage equation for the self-selection of individuals into employment. We estimate the rate of returns for level of education and for years of education. We find relatively low rates of returns for education in terms of wage premia and argue that in countries with chronic labour market disequilibria (such as in Kosovo), the returns for education may be in terms of employment premia. To our knowledge, this is the first systematic study of these issues in this post-socialist and post-conflict economy.

Keywords: returns for education, wage and employment premia, Kosovo, transition economies

JEL: J30, J31

DOI: $10.2478 / v 10033-011-0007-x$

\section{Introduction'}

There is a growing literature supporting the argument that the quantity and quality of human capital is important for economic growth in both developing and developed countries (Canton et al., 2005; Keller, 2006). When transition started, based on indicators of educational attainment, it was argued that the average level of education embodied in the labour force in transition countries was relatively high (Duczynski, 2001; Druska et al., 2002; Spagat, 2006). However, a number of studies suggested that firms in these economies lag behind those in advanced industrialised countries in terms of the quality of their workforce (EBRD, 2000). Beirne and Campos (2007) conclude that the official human capital stock figures were indeed overestimated during socialism. The previous system emphasised narrow technical skills, which were appropriate to the nature of socialist economies (Boeri and Flinn, 1997; Sabirianova, 2000; World Bank, 2000). As revealed later during transition, these skills were not generally valued in the market economy. Druska et al. (2002) argue that there was a significant mismatch between the types of skills that workers possess and the type of skills that the new emerging economy demanded.

In this paper we utilise human capital theory and the Mincerian wage function to estimate the private returns of education in Kosovo. In Section 2, we provide the context of the labour market and education in Kosovo. In Section 3, we survey the literature concerning transition economies and identify the key patterns in the rates of returns of education. In Section 4 we argue that in cases of chronic labour market disequilibria (which is typically the case in Kosovo), the Heckman sample selection model (rather than the conventional Ordinary Least Squares) is the appropriate model to estimate the Mincerian wage

* Avdullah Hoti

University of Prishtina, Faculty of Economy

E-mail: avdullah.hoti@gmail.com 
equation. In Section 5, we consider Riinvest Household Labour Force Survey (HLFS) data regarding employment and wages in Kosovo, identify the sample that we use in our estimations and discuss the choice of, and rationale for, the explanatory variables included in the Mincerian wage equation. In Sections 6 and 7, we present our findings on returns based on level of education and year of education and employment premia, respectively. Section 8 provides a conclusion. Given the noticeable gender differences in almost all labour market outcomes, we pay particular attention to these differences.

\section{Context: The Labour Market and Education in Kosovo}

Kosovo has had a unique history during both the socialist system and the transition process. It was the poorest region in the former Yugoslavia, with a per capita social product of a quarter of the Yugoslav average in 1989 (SOK, 1989; Bevc, 1993). Estimated at 2003 prices, GDP per capita fell from around $€ 1,500$ in 1987 to below $€ 300$ in the late 1990s (World Bank, 2004; Moalla-Fetini et al., 2005). Unlike in other European Transition Countries (ETCs), where output (and employment) decline was due to transitional changes and the associated structural reforms, in Kosovo it was largely due to the absence of such reforms and political unrest. Since emerging from the military conflict and a decade of disinvestment, modest economic growth has been recorded that is mainly attributed to immense international donor support (during 2000-2003 this support totalled €4.1 billion). The GDP is recovering and is estimated to have reached the level of $€ 3.4$ billion in 2007, nearly $€ 1,645$ in per capita terms (MEF, 2008). Despite this increase, GDP per capita in Kosovo is the lowest of all SEE countries."

Labour market developments in Kosovo since the end of the socialist system are different in many respects from those found in other transition economies. Kosovo is known for its young population, implying a large number of new entrants into the labour force each year, which is estimated at 21-25 thousand or 7-8 percent of current employment (Riinvest Institute, 2003). In the early 1990s, some 145,000 workers ( $60 \%$ of employment in 1989) were dismissed from their jobs, which had implications for their labour market status during the post-war period by which time their skills were likely to have deteriorated. Data reported in SOK (2005) suggest that there are large gender differences in all indicators. The female activity rate is very low compared to that of males. On average only 4 out of 10 males and 1 out of 10 females of working age are employed. The unemployment rate of around 40 percent is especially high among females and young persons and around 85 percent of the unemployed are long-term unemployed.

Nearly a quarter of the population is in full-time education (MEST, 2005). Although the number of students in higher education has recently increased, participation at this level is well below the 25 percent found in most European Transition Countries (ETCs) and there are also significant gender differences. The 'parallel system' of education ${ }^{\text {iii }}$ during the 1990s has decelerated the pace of skill formation and is expected to have decreased significantly the average education level of the current working age population. Despite the reforms implemented in the education system, an issue of concern remains the quality of skills obtained by the new graduates. There are indications that employers are not satisfied with the skills of the new graduates (Riinvest Institute, 2003). An important issue is whether the education system is providing the type of skills that are required in a labour market, where new private sector jobs during the last four years have been created in the Small and Medium Enteprises (SMEs) sector.

\section{The Mincerian Wage Equation and Evidence for Transition Economies}

In this section, we briefly consider the Mincerian wage equation and provide evidence on the rates of returns for education for transition economies. At the microeconomic level, the basic Mincerian wage equation (Mincer, 1974) relates the log wage (In $\left.w_{i}\right)$ to years of education $\left(E d_{i}\right)$ and experience $\left(\operatorname{Exp}_{i}\right)$ and its square $\left(\operatorname{Exp}_{i}^{2}\right)$ :

In $w_{i}=\alpha+\theta \operatorname{Ed}_{i}+\varphi_{1} \operatorname{Exp}_{i}+\varphi_{2} \operatorname{Exp}_{i}^{2}+\varepsilon_{i}$

where $\varepsilon_{i}$ is a random error term. The estimated $\theta$ shows the rate of return for years of education, controlling for work experience. The education variable may also be specified in terms of dummies for each educational level, such that:

In $w_{i}=\alpha+\theta \operatorname{Prim}_{i}+\theta \operatorname{Sec}_{i}+\theta \operatorname{igh}_{i}+\varphi_{1} \operatorname{Exp}_{i}+\varphi_{2} \operatorname{Exp}_{i}^{2}+\varepsilon_{i}$

where now the estimated $\theta$ s measure the wage premia associated with each educational level over the base category of education. Unlike Equation (1), which 


\begin{tabular}{|c|c|c|c|c|c|c|c|c|c|}
\hline & Country & & Pre-tran & sition & & & uring tra & nsition & \\
\hline & & Year & Males & Female & All & Year & Males & Females & All \\
\hline & [1] & {$[2]$} & [3] & [3] & [4] & [5] & [6] & [7] & [8] \\
\hline Cheidvasser and Benitez-Silva (2006) & Russia & & & & & $1992-99$ & 3.2 & 4.9 & 4.0 \\
\hline Andren et al. (2004) & Romania & $1950-$ & & & $3-4$ & 2000 & & & 8.5 \\
\hline Münich et al. (2004) & Czech R. & 1989 & 2.7 & 3.9 & & 1996 & $5.8(5.7$ & $7.1(6.8)$ & \\
\hline Campos and Jolliffe (2002) & Hungary & 1986 & & & 6.4 & 1998 & & & 11.2 \\
\hline Clark (2003) & Russia & & & & & $1991-99$ & & & $6-13$ \\
\hline Chase (1998) & Czech R. & 1984 & 2.4 & 4.2 & & 1993 & 5.2 & 5.8 & \\
\hline & Slovakia & 1984 & 2.8 & 4.4 & & 1993 & 4.9 & 5.4 & \\
\hline
\end{tabular}

Table 1: The rate of return based on years of education for selected transition economies before and during transition

provides an estimate on the overall increase in earnings for a year of education, this approach allows for nonlinearity between (though not within) levels of education.

As Heckman et al. (2003) argue, Mincer's framework captures a pricing equation or hedonic wage function revealing how the labour market rewards productive attributes like schooling and work experience. Note that the Mincerian framework neglects other determinants of returns to schooling, such as non-pecuniary returns, ${ }^{\text {iv }}$ taxes, length of working life and uncertainty about future returns at the time schooling decisions are made (Card, 1999; Björklund and Kjellström, 2002; Heckman et al., 2003; Blundell et al. 2005). It also neglects the likelihood of being in employment in the first place, which we explore in this paper. Blundell et al. (1999) and Psacharopoulos and Patrinos (2004) argue that the literature has usually ignored these aspects on the assumption that the pluses and minuses cancel out and one ends up with a net benefit almost equal to the unadjusted one.

For a number of countries, estimates of the rates of returns for education from the Mincerian wage equation are available since the late of 1950s. Psacharopoulos (1973, 1985, 1994) and Psacharopoulos and Patrinos (2002) provide a comprehensive update of the returns for investment in education on a global scale. Their findings suggest that returns for investment in education decline with the level of schooling and women generally enjoy higher rates of returns than their male counterparts. The literature concerning transition economies is large and growing, but cross-country comparison of these rates is not straightforward due to the different methodologies employed to estimate them. Some studies use years of schooling, whereas others use the level of education to yield estimates of the rate of return for schooling.

With the introduction of the market economy in ETCs, two competing extreme hypotheses were put forward regarding the likely changes in the rates of returns for education. (Svejnar, 1999; Newell and Reilly, 1999; Boeri and Terrell, 2002; Campos and Jolliffe, 2002; Münich et al., 2004). The first argued that the socialist system provided an egalitarian distribution of income through maintaining a deliberately compressed wage structure. With the introduction of market-based reforms, wages and prices would adjust to market forces (Orazem and Vodopivec, 1997), hence, rates would rise during the transition compared to their pre-transition level. The competing hypothesis maintained the argument that human capital and experience gained under communism may not be very useful in a market economy, and that therefore the rates of returns for education would fall. In addition, it was also expected that the gender gap in wage differentials would widen and the rate of return for education for female workers would decrease relative to that of male workers.

Estimates of the rates of returns according to years of education for transition economies are presented in Table 1. A general pattern is that the rates increased during transition compared to the pre-transition period, supporting the first hypothesis above. Andren et al. (2004) find for Romania that this rate increased from 3-4 percent during the pre-transition period to 8.5 percent in 2000. A similar pattern is reported for other countries as well.

There are very few studies that provide estimates on returns based on level of education. Pastore and Verashchagina (2006) find for Belarus that male and female university graduates get a wage premia of 74 and 67 percent higher over their counterparts with compulsory education, respectively. Hazans (2005) finds for Latvia that individuals with higher education earn wage premia 80 (50) percent higher than those with basic (secondary) education and the estimated wage premia is higher for females compared to males at each level of education. Münich et al. (2004) find for the Czech Republic that a woman with university education earned on average 45 percent more than a woman with secondary education and that this had increased to 85 
percent by 2002. Orazem and Vodopivec (1997) find for Slovenia that during transition the more educated workers have gained not only in terms of increased relative wages, but they have experienced greater relative success in switching jobs, a lower probability of layoffs and better chances of finding a job if unemployed.

To summarise, the rates of returns for education during transition generally increased compared to the socialist period, giving support to the hypothesis that the socialist system compressed wages artificially.

\section{Estimation Strategy for Kosovo: The Heckman Sample Selection Model}

In much of the transition literature, the Ordinary Least Squared (OLS) model is utilised to estimate the Mincerian wage equation under the assumption that the sample of individuals is a random sample. If this is violated then OLS produces an estimate for $\theta$ in the above equations that is biased and inconsistent. Later in this section, we provide evidence for Kosovo that education (which affects the observed wage) has a non-negligible effect on the probability of being in employment, suggesting that the sample of employed individuals is a non-random sample. To account for this selectivity bias we utilise the Heckman correction model (Heckman, 1979). This model initially controls for the selection into employment (the sample consisting of employees and unemployed persons) and then the wage equation is estimated from the sample of employees after controlling for selection.

The nature of the selection mechanism in our case is such that we observe an individual's wage $(w)$ only when some criteria is met (when a person is employed, denoted by $y=1$ ). This is incidental truncation, since wage is missing because of another variable (employment status) and the selection into the sample is due to the behaviour of individuals and not due to the sample design. Following Wooldridge (2002), this selection mechanism can be expressed by the following equations:

$$
\begin{aligned}
& w=x_{1} \beta+u_{1} \\
& y=1\left(x_{2} \gamma+u_{2}>0\right)
\end{aligned}
$$

which are referred to as the main and the selection equations, respectively. The following assumptions apply: (i) $y, x_{1}$ and $x_{2}$ are always observed and $w$ is observed only when $y=1$; (ii) $\left(u_{1}, u_{2}\right)$ is independent of $x_{2}$ with zero mean; (iii) $u_{2} \sim \operatorname{Normal}(0,1) ;$ and (iv) $E\left(u_{1} \mid u_{2}\right)=\rho u_{2}$.
Wooldridge (2002) shows that if $\rho \neq 0$ then $u_{1}$ and $u_{2}$ are correlated, implying that there is a sample selection problem and that OLS estimation of Equation (3) produces biased estimates of $\beta$. In the estimation, exclusions restrictions in the main equation should be applied to identify $\beta$, i.e. $x_{2}$ should include at least one variable that is not also included in $x_{1}$ and which is expected to have a significant impact on selection. In addition, $x_{1}$ should be a strict subset of $x_{2}$. This is often a problem in empirical estimations, because the additional variable in $x_{2}$ should be expected to affect employment status, but not the wage itself. We use the partial Maximum Likelihood (ML) approach to estimate the Heckman selection model.

\section{The Sample and Some Descriptive Statıstics}

We use the data from the Riinvest Household and Labour Force Survey (HLFS) conducted in December 2002. The sample consisted of 1,252 households (randomly selected after sample stratifications by the 7 regions in Kosovo and urban/rural areas) with 8,552 members, an estimated 0.45 percent of the population of Kosovo. Figure $\mathrm{A} 1$ in the Appendix shows how an individual's labour force status is determined in this survey, which complies with international labour standards (ILO, 1982; ILO 2005). Following the ILO guidelines we find that out of 4,460 working age individuals (16-64), ${ }^{\vee} 2,731$ are active in the labour force. Out of labour force participants, 1,422 are employed (52 percent) and 844 (59.4 percent) of the employed are employees or wage earners. The rest are self-employed, workers in their family business or farm etc., that we refer to as non-wage earners. The human capital theory underpinning the Mincerian wage equation is related to estimating the wage differentials due to education for employees only. Therefore, in line also with other studies (Orazem and Vodopivec, 1997; Newell and Reilly, 1999; Camposs and Jolliffe, 2002; Münich et al., 2004), in estimating the Mincerian wage equation we only use observations for employees.

Due to missing data on wages, we have to drop 13 observations on employees (1.5 percent of all employees) and therefore have 831 observations. This approach of listwise deletion is arguably acceptable, since the missing data comprise a small percentage of total cases (Cameron and Trivedi, 2005),

Therefore, our sample consists of 831 observations of employees and 1,309 of unemployed persons presented 


\begin{tabular}{|c|c|c|c|c|}
\hline & Employees & Unemployed & Total & $\begin{array}{l}\text { t-tests of equal means or } \\
\text { equal proportions } \mathrm{H}_{0} \text { : }\end{array}$ \\
\hline & [1] & [2] & [3] & [4] \\
\hline Observations & 831 & 1309 & 2,140 & \\
\hline Males (proportion) & 0.733 & 0.538 & 0.614 & Rejected \\
\hline Average age & 39.48 & 30.45 & 33.95 & Rejected \\
\hline \multicolumn{5}{|l|}{ Age structure } \\
\hline $16-24$ & 0.089 & 0.361 & 0.255 & Rejected \\
\hline $25-34$ & 0.264 & 0.325 & 0.301 & Rejected \\
\hline $35-44$ & 0.297 & 0.201 & 0.238 & Rejected \\
\hline $45-54$ & 0.255 & 0.079 & 0.148 & Rejected \\
\hline $55-64$ & 0.095 & 0.034 & 0.058 & Rejected \\
\hline \multicolumn{5}{|l|}{ Educational level* } \\
\hline Less than upper-secondary & 0.142 & 0.368 & 0.28 & Rejected \\
\hline Upper-secondary & 0.537 & 0.571 & 0.557 & Not \\
\hline Higher & 0.319 & 0.057 & 0.158 & Rejected \\
\hline No answer ** & 0.002 & 0.005 & 0.004 & - \\
\hline Education (average years) & 12.04 & 10.61 & 11.31 & Rejected \\
\hline Marital status (married) & 0.805 & 0.537 & 0.641 & Rejected \\
\hline
\end{tabular}

Source of data: Riinvest HLFS of December 2002; ${ }^{*}$ A small proportion of those with a higher education degree have completed only 2 years of higher education. The majority have completed 4 or 5 years depending on the type of higher education, with very few having a Master's or a PhD degree. On average, this would give 4 years of higher education for all those with a higher education degree. Similarly, those with less than upper-secondary education includes a number of individuals (usually older people) with less then primary education.** In the estimation these few observations are included in the base category of education (less than upper-secondary) since they are largely older.

Table 2: The characteristics of the sample used in the wage equation utilising the Heckman selection model

in Table 2 (columns 1 and 2, respectively). From column 4 of Table 2, findings from the $t$-test suggest that most of the observed differences between the employed and unemployed workers are statistically significant, indicating that there may be sample selection (i.e. the sample of employees is not a random sample of the labour force).

Nearly half of all employees (47 percent) are working in the public sector (see Table A1). As shown in Table A2, the average gross monthly wage for females of $€ 178$ (s.d. 8) is lower than for males of $€ 229$ (s.d. 6). From column 4, the ratio of female to male average wage is 0.78 and the gap is larger in the private sector. The distribution of monthly wages by gender follows the expected pattern of lower average wages for females (Figure A2 in Appendix). Based on human capital theory, this pattern may be explained by: (i) their lower education level and work experience than males; (ii) from choosing occupations where the increase in wages due to experience is lower (supply-side argument); and (iii) rejecting the assumption of a competitive labour market, as well as due to discrimination in the labour market (demand-side argument). Figure A3 shows the relative wage compared to a less than upper secondary completed level of education. The relative increase in wages due to education is larger among female employees. Furthermore, from Figure A4, in addition to higher average wages, a higher education level is associated with a significant increase in the likelihood of being an employee. This may suggest that part of the returns for education may take the form of employment premia.

The evidence from the descriptive statistics and the $t-$ tests is supportive of the argument that the employed sample is not a random sample of individuals in the labour force and hence indicates the need to use the Heckman sample selection model to estimate returns to education, or some other model that can account for a selectivity bias.

We estimate two specifications of the Mincerian wage equation as shown by Equations (1) and (2) above. In the returns based on years of education specification (1), we impute years of education from the reported level of education ${ }^{\text {vi }}$ and estimate the average increase in earnings due to years of education. However, such an imputation of data causes a problem in statistical inference and does not allow for non-linearity in the returns for education. Another problem is that for some individuals it may take more years than is usual to attain a given level of education. In addition, this approach does not allow for a sheepskin effect, because each year of education yields the same rate of return. It is estimated here to allow 


\begin{tabular}{|c|c|c|c|c|c|c|c|c|}
\hline & Males & & Females & & Males & & Eemales & \\
\hline \multirow{2}{*}{ Explanatory variables } & Coeff. & $z$ & Coeff. & z & Coeff. & z & Coeff. & z \\
\hline & [1] & & {$[2]$} & & [3] & & [4] & \\
\hline \multicolumn{9}{|l|}{ A: Wage equation } \\
\hline Constant & $5.462^{* * *}$ & 12.34 & $2.789^{* * *}$ & 4.48 & $5.113^{* * *}$ & 44.99 & $4.407^{* * *}$ & 16.84 \\
\hline Upper-secondary education & -0.004 & -0.06 & $0.324^{* * *}$ & 2.60 & 0.088 & 1.30 & $0.247^{*}$ & 1.86 \\
\hline Higher education & 0.113 & 1.21 & $0.699^{* * *}$ & 4.14 & $0.258^{* * *}$ & 2.64 & $0.543^{* * *}$ & 2.57 \\
\hline Age & 0.006 & 0.32 & $0.075^{* * *}$ & 2.76 & & & & \\
\hline Age squared & -0.0002 & -0.90 & $-0.001^{* * *}$ & -2.75 & & & & \\
\hline \multicolumn{9}{|l|}{ B: Selection equation } \\
\hline Constant & $-2.901^{* * *}$ & -6.42 & $-3.752^{* * *}$ & -6.16 & $-2.956^{* * *}$ & -6.61 & $-3.299^{* * *}$ & -5.27 \\
\hline Upper-secondary education & $0.436^{* * *}$ & 4.57 & $0.894^{* * *}$ & 7.05 & $0.442^{* * *}$ & 4.64 & $0.893^{* * *}$ & 7.06 \\
\hline Higher education & $1.124^{* * *}$ & 8.84 & $1.613^{* * *}$ & 9.38 & $1.117^{* * *}$ & 8.80 & $1.655^{* * *}$ & 9.66 \\
\hline Age & $0.087^{* * *}$ & 3.29 & $0.111^{* * *}$ & 3.15 & $0.090^{* * *}$ & 3.48 & $0.083^{* *}$ & 2.35 \\
\hline Age squared & $-0.001^{* *}$ & -2.17 & $-0.001^{* *}$ & -2.23 & $-0.001^{* *}$ & -2.25 & -0.001 & -1.44 \\
\hline Married & $0.360^{* * *}$ & 3.12 & -0.034 & -0.33 & $0.286^{* *}$ & 2.43 & -0.018 & -0.16 \\
\hline \multicolumn{9}{|c|}{ Likelihood Ratio test of independent } \\
\hline Log likelihood & -1227.61 & & -540.94 & & -1233.14 & & -544.89 & \\
\hline Wald test, $\chi^{2}$ (4) and $\chi^{2}$ (2) & 19.36 & & 22.38 & & 7.49 & & 6.68 & \\
\hline All observations & 1,313 & & 827 & & 1,313 & & 827 & \\
\hline Censored observations & 704 & & 605 & & 704 & & 605 & \\
\hline Uncensored observations & 609 & & 222 & & 609 & & 222 & \\
\hline
\end{tabular}

$* * *, * *, *$ significant coefficient at 1,5 and 10 percent, respectively.

The dependent variable in panel $A$ is the log monthly wage

The dependent variable in panel $B$ equals 1 if an employee and 0 if unemployed

Table 3: Estimates of the returns based on level of education

comparisons to other studies, many of which follow this approach of estimating the returns based on years of education.

Data regarding work experience is not available. As in other studies, we initially use age and its square to proxy for experience. However, this is with reservation, as in Kosovo, given its high current as well as previous unemployment rate, age is likely to be a poor and probably inappropriate proxy. We do not include other control variables in the wage equation (e.g. sector of employment, company's ownership etc.). A simple specification of the Mincerian wage equation with only human capital variables is suggested if one intends to estimate the total effect of education on earnings (Psacharopoulos and Patrinos, 2002; Pereira and Martins, 2004; Psacharopoulos and Patrinos, 2004).

In the selection equation, the dependent variable equals 1 if the individual is an employee and 0 if unemployed. In the selection equation we also include marital status (dummy equals 1 if married). In the case of females, we expect that being married lowers the likelihood of employment because of both higher opportunity costs of employment and the traditional nature of the Kosovan society, where women are regarded as the second earner in the household. For males, being married is expected to have a positive effect on employment due to the greater need to provide additional income for the extended household.

\section{Findings: Returns for Education in Terms of Higher Wages}

In this section, we present our findings and compare them with those found elsewhere in transition economies. We estimate separate regressions for males and females given the argument in Section 6 above.

\subsection{Returns Based on Level of Education}

Our estimates on returns based on level of education are presented in panel $A$ of Table 3 (columns 1 and 2 for males and females respectively). The estimated $\rho$ (in the bottom panel of the table) is, unexpectedly, insignificant for both genders. For males, apart from the constant term, all other coefficients in the wage equation are insignificant. ${ }^{\text {vii }}$ The reason for these results is not clear. It does not seem to be due to problems with identification, since the coefficient on marital status in the selection 


\begin{tabular}{|c|c|c|c|c|c|c|c|c|}
\hline \multirow[b]{2}{*}{ Explanatory variables } & \multicolumn{2}{|l|}{ Males } & \multicolumn{2}{|l|}{ Females } & \multicolumn{2}{|l|}{ Males } & \multicolumn{2}{|l|}{ Females } \\
\hline & Coeff. & $z$ & Coeff. & Z & Coeff. & z & Coeff. & z \\
\hline & [1] & & [2] & & [3] & & [4] & \\
\hline \multicolumn{9}{|l|}{ A: Wage equation } \\
\hline Constant & $5.091^{* * *}$ & 9.95 & $2.056^{* * *}$ & 2.91 & $4.840^{* * *}$ & 25.48 & $3.814^{* * *}$ & 8.45 \\
\hline Years of education & $0.020^{*}$ & 1.68 & $0.096^{* * *}$ & 4.40 & $0.033^{* * *}$ & 2.85 & $0.075^{* * *}$ & 2.82 \\
\hline Age & 0.011 & 0.59 & $0.070^{* * *}$ & 2.63 & & & & \\
\hline Age squared & -0.0002 & -1.08 & $-0.001^{* *}$ & -2.56 & & & & \\
\hline \multicolumn{9}{|l|}{ B: Selection equation } \\
\hline Constant & $-4.089^{* * *}$ & -8.73 & $-5.378^{* * *}$ & -8.40 & $-4.131^{* * *}$ & -8.91 & $-5.036^{* * *}$ & -7.78 \\
\hline Years of education & $0.135^{* * *}$ & 8.29 & $0.213^{* * *}$ & 9.54 & $0.136^{* * *}$ & 8.33 & $0.217^{* * *}$ & 9.65 \\
\hline Age & $0.088^{* * *}$ & 3.32 & $0.108^{* * *}$ & 3.05 & $0.090^{* * *}$ & 3.46 & $0.084^{* *}$ & 2.38 \\
\hline Age squared & $-0.001^{* *}$ & -2.09 & $-0.001^{* *}$ & -2.08 & $-0.001^{* *}$ & -2.15 & -0.001 & -1.40 \\
\hline Married & $0.364^{* * *}$ & 3.12 & -0.023 & -0.22 & $0.307^{* * *}$ & 2.63 & -0.005 & -0.05 \\
\hline $\begin{array}{l}\text { Likelihood Ratio test of independent } \\
\left.\text { equations [i.e. }=0,{ }^{2}(1)\right]\end{array}$ & 0.43 & & 2.80 & & 1.77 & & 3.80 & \\
\hline Log likelihood & -1230.9 & & -541.6 & & -699.3 & & -358.5 & \\
\hline Wald test, ${ }^{2}(2)$ & 17.10 & & 23.57 & & 10.12 & & 7.75 & \\
\hline All observations & 1,313 & & 827 & & 1,313 & & 827 & \\
\hline Censored observations & 704 & & 605 & & 704 & & 605 & \\
\hline Uncensored observations & 609 & & 222 & & 609 & & 222 & \\
\hline
\end{tabular}

Table 4: Estimates of the rate of return based on years of education

equation (panel $B$, column 1 ) is significant for males. These unexpected results might be due to the age variable proxy for experience as noted above (i.e. on-thejob training) being a poor and probably inappropriate proxy in the case of Kosovo. For females, all coefficients in the wage equation are significant (column 2) and with the expected signs, but there is also an insignificant coefficient for $\rho$.

Given our strong reservations on using age as a proxy for experience, we estimated the relationships without age and aged squared in the Mincer equation as shown in columns 3 and 4 of Table 3 (for males and females respectively). In these revised specifications, there is a significant coefficient on the educational dummy for higher education for both genders in the wage equation. The coefficient on the educational dummy for uppersecondary education is not significant for males, while for females it is significant only at the 10 percent level.

Bearing these problems in mind, we now discuss these estimates and consider what they indicate about the wage premia due to education. For both genders, the coefficients on educational dummies suggest that average returns to education increase with education: males with upper-secondary and higher education get wages on average 9.2 and 29.4 percent higher than males with less than upper-secondary education, respectively; for females, the estimated wage premia are 28.0 percent and 72.1 percent for upper-secondary and higher education, respectively.

There is no previous study for Kosovo with which to compare our findings. The only previous relevant study is Bevc (1993), and which utilises a cost-benefit analysis approach to estimate the average returns for education for Kosovo and for other regions of the former Yugoslavia for 1976 and 1986 (the socialist period). She finds that the average rate of return decreased with a region's stock of educational capital and with the level of economic development. Kosovo had the highest rates of return for education in the former Yugoslavia. However, any comparison with our findings is difficult due to differences in the estimation approach used. Compared to findings from other transition countries, the estimated wage premia in Kosova are lower even when we consider the revised model, particularly for males. 


\begin{tabular}{|c|c|c|c|c|c|c|}
\hline & \multicolumn{2}{|c|}{ Age 25} & \multicolumn{2}{|c|}{ Age 34} & \multicolumn{2}{|c|}{ Age 40} \\
\hline & Male & Female & Male & Female & Male & Female \\
\hline & [1] & {$[2]$} & [3] & {$[4]$} & [5] & {$[6]$} \\
\hline \multicolumn{7}{|l|}{ A. Probability of being an employee for a married person with:* } \\
\hline - less than upper-secondary education & 0.15 & 0.03 & 0.22 & 0.05 & 0.25 & 0.06 \\
\hline - upper-secondary education & 0.27 & 0.17 & 0.37 & 0.22 & 0.41 & 0.24 \\
\hline - higher education & 0.53 & 0.42 & 0.64 & 0.50 & 0.67 & 0.52 \\
\hline $\begin{array}{l}\text { B. Change in the percentage points in the probability of being } \\
\text { employee due to an additional year of education for a married } \\
\text { person (from- to) ** }\end{array}$ & $2-6$ & $2-9$ & 4-5 & $3-8$ & $4-5$ & $3-7$ \\
\hline
\end{tabular}

\subsection{Returns based on years of education}

Table 4 gives the estimates using the imputed years of education and estimate the rate of return based on years of education. In columns 1 and 2 we face similar results as in our previous estimation, with education only significant at the 10 percent level for males and with an insignificant sample selection coefficient. In the estimation without age and age squared in columns 3 and 4, we again find a significant coefficient on years of education for both genders. For females, there is now evidence of sample selection, although only at the 10 percent level.

The estimated rate of return based on years of education from panel $A$ (columns 3 and 4 ) is 3.3 percent for males and 7.5 percent for females. In the case of males, these rates are again low relative to those for the other transition economies summarised above.

In our most favourable case, our estimates of the wage premia due to education are low relative to other transition economies, particularly for males. A low wage premia due to education in Kosovo may be partly explained by the excess labour supply at each level of education. The descriptive statistics from the Riinvest HLFS discussed above suggest that unemployment for those with higher education is still as high as 20 percent, reaching the level of more than 60 percent for those with less than upper-secondary education. This excess labour supply may suppress wage differentials due to education, as workers are likely to trade lower wages for more secure employment. This implies that in a high unemployment economy part of the return to education takes the form of employment premia rather than higher wages. We now investigate this possibility.

\section{Findings: Returns for Education in Terms of Employment Premia}

Given the findings above of a relatively low wage premia due to education, there may be other forms of returns so that individuals find it worthwhile investing in education. Panel $A$ of Table 5 gives the estimated probability of being an employee for each level of education (for males and females at different ages) derived from the estimates of the selection equation presented in Table 3. For a 34 year old male (sample average) that is married and with less than an uppersecondary education, the probability of being an employee is 0.22 , while for a similar female it is as low as 0.05 . With upper-secondary education, this probability increases to 0.37 for males and 0.22 for females, and for higher education increases to 0.64 for males and 0.50 for females. From panel $B$, derived from the estimates of the selection equation presented in Table 4, at age 34 an additional year of education increases the probability of being an employee from 4 to 5 percentage points for males and from 3 to 8 percentage points for females (depending on the starting year of education). For females, the marginal increase associated with each level of education is higher than for males.

\section{Conclusions}

In this paper, we investigated the private returns for education in Kosovo and found that our estimates are noticeably different compared to those found elsewhere in ETCs. Our investigations of the data suggest that the level of completed education is an important determinant of the incidence of employment, implying that the employed are likely to be a non-random sample of labour force participants. To account for this in the estimation of returns for education we utilised the 
Heckman sample selection model. We identified the difficulties encountered in applying this model to Kosovo and related concerns may apply more generally in empirical work on ETCs.

We find low returns for education in terms of wage premia relative to other transition economies, particularly for males. Returns for education are higher for females than for males and these returns increase with educational level. Such low wage premia are to be expected in high unemployment economies where workers are likely to trade off lower wages for more secure employment. Blundell et al. (2005) argue that if wage differentials due to education reflect changes in productivity then the estimated rates of returns to education provide evidence of productivity differences associated with education. On this basis, our results could imply a relatively low value of education in Kosovo in terms of improving productivity in the workplace. Although this possibility cannot be ruled out, we consider another explanation for these low rates of returns. We argue that poor job prospects weaken the bargaining position of employees, leading them to trade lower wages in return for more secure employment. Assuming some minimum reservation wage, this makes wages more compressed, resulting in low returns for education in terms of wage premia. Our econometric results suggest there is a large increase in the likelihood of being in waged employment due to education, consistent with the argument that in high unemployment economies part of the total returns for education takes the form of employment premia.

\section{References}

Andren, D., Earle, J., Sapatoru, D. (2004): The wage effects of schooling under socialism and in transition: Evidence from Romania, 1950-2000; Upjohn Institute, Staff working paper 108

Beirne, J. and Campos, N. (2007): Educational inputs and outcomes before the transition from communism; Economics of Transition, 15(1): 57-76

Bevc, M. (1993): Rates of return to investment in education in former Yugoslavia in the 1970s and 1980s by region; Economics of Education Review, 12(4): 325-343

Björklund, C. and Kjellström (2002): Estimating the return to investments in education: how useful is the standard Mincer equation?; Economics of Education Review, 21(3): 195-210

Blundell, R. Dearden, L. Meghir, C., Sianesi, B. (1999): Human capital investment: The returns from education and training to the individual, the firm and the economy; Fiscal Studies, 20(1): 1-23

Blundell, R., Dearden, L., Sianesi, B. (2005): Measuring the return to education; in What's the good of education? The economics of education in the UK, Machin, S. and Vignoles, A. (ed), Princeton University Press, Princeton and Oxford

Boeri, T. and Flinn, C. (1997): Returns to mobility in the transition to a market economy; IGIER, Working paper 123

Boeri, T. and Terrell, K. (2002): Institutional determinants of labour reallocation in transition; Journal of Economic Perspectives, 16(1): 51-76

Cameron, A. and Trivedi, P. (2005): Microeconometrics: Methods and applications; Cambridge University Press, New York

Campos, N. and Jolliffe, D. (2002): After, before and during: Returns to education in the Hungarian transition; IZA, Discussion paper 475

Canton, E., Minne, B., Nieuwenhuis, A., Smid, B., van der Steeg, M. (2005): Human capital, R\&D, and competition in macroeconomic analysis; Netherlands Bureau for Economic Policy Analysis, CPB document 91

Card, D. (1999): The causal effects of education on earnings, in Handbook of Labor Economics, Ashenfelter, O. and Card. D. (ed.), 3(A): 1801-1863, Amsterdam: North Holland

Chase, R. (1998): Markets for communist human capital: Returns to education and experience in the Czech Republic and Slovakia; Industrial and Labor Relations Review, 51(3): 401-423

Cheidvasser, S. and Benitez-Silva, H. (2006): The educated Russian's curse: Returns to education in the Russian Federation during the 1990s; Forthcoming in Review of Labour Economics and Industrial Relations

Clark, A. (2003): Returns to human capital investment in a transition economy: The case of Russia, 1994-1998; International Journal of Manpower, 24(1): 11-30

Druska, V., Jeong, B., Kejak, M., Vinogradov, V. (2002): Assessing the problem of human capital mismatch in transition countries; William Davidson Institute, Working paper 467

Duczynski, P. (2001): On educational attainment in transition economies; Prague Economic Papers, 10(2): 163-173

EBRD (2000): Transition Report 2000: Employment, skills and transition; EBRD, London

Hazans, M. (2002): Age-earnings profile and human capital in transition: Evidence from the Baltic states; EuroFaculty, Working paper 14

Heckman, J. (1979): Sample selection bias as a specification error; Econometrica, 47(1): 153-161

Heckman, J., Lochner, L. and Todd, P. (2003): Fifty years of Mincer earnings regressions; IZA, Discussion paper 775

ILO (1982): Resolution concerning statistics of the economically active population, employment, unemployment, and underemployment; Thirteenth International Conference of Labour Statisticians, International Labour Organisation, October 1982, Geneva

ILO (2002): Key indicators of the labour market 2001-2002; International Labour Office, Geneva

Keller, K. (2006): Investment in primary, secondary, and higher education and the effects on economic growth; Contemporary Economic Policy, 24(1): 18-34

MEF (2008): Semi-annual macroeconomic bulletin; Ministry of Economy and Finacn, Issues 1

MEST (2004): Strategy for development of higher education in Kosova 2005-2015; Ministry of Education, Science and Technology, Prishtina

MEST (2005): Statistical data on education system in Kosova; Ministry of Education, Science and Technology, Prishtina, Prishtina

Micklewright, J. (2000): Education, inequality and transition; UNICEF, Innocenti working paper 74 
Mincer, J. (1974): Schooling, experience, and earnings; Colombia Press, New York

Münich, D., Svejnar, J. Terrell, K. (2004): Do markets favor women's human capital more than planners?; IZA, Discussion paper 1393

Newell, A., and Reilly, B. (1999): Rates of return to educational qualifications in the transitional economies; Education Economics, 7(1): 67-84

Newell, A., and Reilly, B. (2001): The gender pay gap in the transition from communism: Some empirical evidence; IZA, Discussion paper 268

Orazem, P. and Vodopivec, M. (1997): Value of human capital in transition to market: Evidence from Slovenia; European Economic Review, 41(3-5): 893-903

Pastore, F. and Verashchagina, A. (2006): Private returns to human capital over transition: A case study of Belarus; Economics of Education Review, 25(1): 91-107

Pereira, O. and Martins, S. (2004): Returns to education and wage equations; Applied Economics, 36(6): 525-531

Psacharopoulos, G. (1973): Returns to education: An international comparison; Elsevier, Amsterdam

Psacharopoulos, G. (1985): Returns to education: A further international update and implications; Journal of Human Resources, 20(4): 583-604

Psacharopoulos, G. (1994): Returns to investment in education: A global update; World Development, 22(9): 1325-1343

Psacharopoulos, G. and Patrinos, H. (2002): Returns to investment in education: A further update; World Bank Policy Research, Working paper, 2881

Psacharopoulos, G. and Patrinos, H. (2004): Human capital and rates of return; in International Handbook on the Economics of Education, Johnes, G. and Johnes, J. (ed), pp.1-57, Edward Elgar Publishing Ltd.

Riinvest Institute (2003): Labour market and unemployment in Kosova; Riinvest Institute, Prishtina

Riinvest Institute (2004): Education and economic development of Kosova; Riinvest Institute, Prishtina

SOK (1989): Statistical yearbook of SAP of Kosova; Statistical Office of Kosova, Prishtina, in Albanian

SOK (2005): Labour force survey 2004: Key employment Indicators; Statistical Office of Kosova, Prishtina

Spagat, M. (2002): Human capital, growth and inequality in transition economies; William Davidson Institute, Working paper 499

Spagat, M. (2006): Human capital and the future of transition economies; Journal of Comparative Economics, 34(1): 44-56

Svejnar, J. (1999): Labour markets in transition Central and East European Countries; in Handbook of Labor Economics, Ashenfelter, O. and Card. D. (ed.), 3(A): 2809-2857, Amsterdam: North Holland

Trostel, P., Walker, I., Woolley, P. (2002): Estimates of the economic return to schooling for 28 countries, Labour Economics, 9(1): 1-16

Wooldridge, J. (2002): Econometric analysis of cross section and panel data; The MIT Press, Cambridge

World Bank (2000): Hidden challenges to education systems in transition economies; The World Bank, Europe and Central Asia Region

World Bank (2004): Kosovo economic memorandum; World Bank, Europe and Central Asia Region, Report 28023-KOS

\section{End notes}

'I would like to thank Professor Nick Adnett and Jean Mangan from Staffordshire University (United Kingdom) for their useful comments as well as the Riinvest Institute (Kosova) for allowing me to use the data for this research.

ii Albania $€ 2,140$, Bosnia and Herzegovina $€ 1,961$, Bulgaria $€ 2,771$, Croatia $€ 6,972$, Macedonia $€ 2,280$, Romania $€ 3,665$, Slovenia $€ 13,675$, Serbia $€ 2,583$ and Montenegro $€ 2,600$ (WIIW, 2007).

iii This parallel system of education was in fact an underground education system, which was organised and financed by the Albanian population in Kosovo. This followed the closure of the schools for the Albanian students by Serbia in 1991.

iv Including better health, improved habits, consumption aspects of education, ability to process and use information etc.

${ }^{*}$ After excluding emigrants and those in full-time education.

vi Less than upper-secondary 8 years (cumulatively 8 years); uppersecondary 4 years (cumulatively 12 years); higher education 2 years for less then BA, 4 years for BA, 6 years for MA and 8 years for PhD (cumulatively 14, 16, 18 and 20 years respectively).

vii We tried with age minus years of education minus 6 , but it made no significant difference. 


\section{Appendix: Tables and Figures}

\begin{tabular}{|c|c|c|c|c|c|c|}
\hline & \multicolumn{3}{|c|}{ Number } & \multicolumn{3}{|c|}{ Proportion } \\
\hline & Females & Males & TotalF & Females & Males & Total \\
\hline & [1] & [2] & [3] & [4] & [5] & [6] \\
\hline Observations & 222 & 609 & 831 & 0.267 & 0.733 & 1.000 \\
\hline \multicolumn{7}{|l|}{ Ownership of the company } \\
\hline Private & 47 & 172 & 219 & 0.212 & 0.282 & 0.264 \\
\hline Public & 122 & 271 & 393 & 0.550 & 0.445 & 0.473 \\
\hline Socially Owned Enterprises & 36 & 127 & 163 & 0.162 & 0.209 & 0.196 \\
\hline Foreign firm & 15 & 28 & 43 & 0.068 & 0.046 & 0.052 \\
\hline Non-Governmental Organisations & 1 & 4 & 5 & 0.005 & 0.007 & 0.006 \\
\hline No answer & 1 & 7 & 8 & 0.005 & 0.011 & 0.010 \\
\hline \multicolumn{7}{|l|}{ Sector of employment } \\
\hline Agriculture & 0 & 8 & 8 & 0.000 & 0.013 & 0.010 \\
\hline Mining & 0 & 24 & 24 & 0.000 & 0.039 & 0.029 \\
\hline Industry & 7 & 47 & 54 & 0.032 & 0.077 & 0.065 \\
\hline Construction & 2 & 52 & 54 & 0.009 & 0.085 & 0.065 \\
\hline Transportation and communications & 3 & 39 & 42 & 0.014 & 0.064 & 0.051 \\
\hline Utilities (water, electricity, waste disposal, etc.) & 12 & 73 & 85 & 0.054 & 0.120 & 0.102 \\
\hline Trade and storage & 18 & 44 & 62 & 0.081 & 0.072 & 0.075 \\
\hline Finance (banking, insurance, real estate, etc.) & 9 & 22 & 31 & 0.041 & 0.036 & 0.037 \\
\hline Administration, justice and police & 16 & 57 & 73 & 0.072 & 0.094 & 0.088 \\
\hline Health and education & 104 & 114 & 218 & 0.468 & 0.187 & 0.262 \\
\hline Restaurants and hotels & 4 & 28 & 32 & 0.018 & 0.046 & 0.039 \\
\hline Gas stations and car repair & 20 & 46 & 66 & 0.090 & 0.076 & 0.079 \\
\hline Other services & 26 & 50 & 76 & 0.117 & 0.082 & 0.091 \\
\hline No answer & 1 & 5 & 6 & 0.005 & 0.008 & 0.007 \\
\hline \multicolumn{7}{|l|}{ Company size } \\
\hline Small (1-4 persons) & 24 & 99 & 123 & 0.108 & 0.163 & 0.148 \\
\hline Medium (5-49 persons) & 91 & 218 & 309 & 0.410 & 0.358 & 0.372 \\
\hline Large (50+) & 90 & 253 & 343 & 0.405 & 0.415 & 0.413 \\
\hline No answer & 17 & 39 & 56 & 0.077 & 0.064 & 0.067 \\
\hline \multicolumn{7}{|l|}{ Payment period } \\
\hline Monthly & 221 & 588 & 809 & 0.995 & 0.966 & 0.974 \\
\hline Bimonthly & 0 & 5 & 5 & 0.000 & 0.008 & 0.006 \\
\hline Weekly & 0 & 1 & 1 & 0.000 & 0.002 & 0.001 \\
\hline Daily & 1 & 15 & 16 & 0.005 & 0.025 & 0.019 \\
\hline
\end{tabular}

Source of data: Riinvest HLFS of December 2002.

Table A1: The characteristics of the sample of employees with data on wages 
(in $€ /$ month, not including food and travel allowances)

\begin{tabular}{|c|c|c|c|c|}
\hline & Females & Males & $\begin{array}{c}\text { All } \\
\text { employees } \\
\end{array}$ & $\begin{array}{c}\text { Female to male } \\
\text { wage ratio }\end{array}$ \\
\hline & [1] & {$[2]$} & [3] & [4] \\
\hline Observations & 222 & 609 & 831 & - \\
\hline The average wage for all observations & 178 & 229 & 215 & 0.778 \\
\hline \multicolumn{5}{|l|}{ By average age } \\
\hline $16-24$ & 172 & 225 & 206 & 0.764 \\
\hline $25-34$ & 209 & 238 & 229 & 0.878 \\
\hline $35-44$ & 178 & 261 & 235 & 0.681 \\
\hline $45-54$ & 139 & 207 & 194 & 0.670 \\
\hline $55-64$ & 134 & 188 & 180 & 0.713 \\
\hline \multicolumn{5}{|l|}{ By residence } \\
\hline Urban residents & 182 & 256 & 232 & 0.710 \\
\hline Rural residents & 166 & 194 & 189 & 0.858 \\
\hline \multicolumn{5}{|l|}{ By education } \\
\hline Less than upper-secondary & 154 & 210 & 197 & 0.734 \\
\hline Upper-secondary & 176 & 227 & 212 & 0.777 \\
\hline Higher & 191 & 242 & 229 & 0.791 \\
\hline \multicolumn{5}{|l|}{ No answer } \\
\hline \multicolumn{5}{|l|}{ By ownership of the company } \\
\hline Private & 186 & 264 & 247 & 0.704 \\
\hline Public & 146 & 181 & 170 & 0.802 \\
\hline Socially Owned Enterprises & 167 & 192 & 187 & 0.870 \\
\hline Foreign & 452 & 575 & 532 & 0.786 \\
\hline \multicolumn{5}{|l|}{ By sector of employment } \\
\hline Agriculture & & 167 & 167 & - \\
\hline Mining & & 190 & 190 & - \\
\hline Industry & 147 & 188 & 183 & 0.782 \\
\hline Construction & 444 & 275 & 281 & 1.614 \\
\hline Transportation and communications & 230 & 236 & 235 & 0.976 \\
\hline Utilities (water, electricity, waste disposal, etc.) & 185 & 206 & 203 & 0.900 \\
\hline Trade and storage & 170 & 230 & 213 & 0.739 \\
\hline Finance (banking, insurance, real estate, etc.) & 237 & 400 & 352 & 0.593 \\
\hline Administration, justice and police & 233 & 229 & 230 & 1.018 \\
\hline Health and education & 142 & 166 & 155 & 0.853 \\
\hline Restaurants and hotels & 158 & 256 & 244 & 0.615 \\
\hline Gas stations and car repair & 251 & 258 & 256 & 0.975 \\
\hline Other services & 137 & 142 & 141 & 0.963 \\
\hline \multicolumn{5}{|l|}{ By company size } \\
\hline Small (1-4 persons) & 161 & 240 & 224 & 0.673 \\
\hline Medium (5-49 persons) & 166 & 233 & 213 & 0.715 \\
\hline Large $(50+)$ & 191 & 213 & 207 & 0.895 \\
\hline No answer & 184 & 280 & 251 & 0.657 \\
\hline \multicolumn{5}{|l|}{ By payment period } \\
\hline Monthly & 177 & 223 & 210 & 0.793 \\
\hline Bimonthly & & 710 & 710 & - \\
\hline Weekly & & 129 & 129 & - \\
\hline Daily & 538 & 308 & 323 & 1.744 \\
\hline \multicolumn{5}{|l|}{ By job tenure } \\
\hline Less then 1 year & 198 & 319 & 312 & 0.62 \\
\hline $1-5$ years & 222 & 293 & 277 & 0.76 \\
\hline More then 5 years & 166 & 215 & 203 & 0.77 \\
\hline
\end{tabular}

Source of data: Riinvest HLFS of December 2002.

Table A4: Average gross monthly wages from main job 


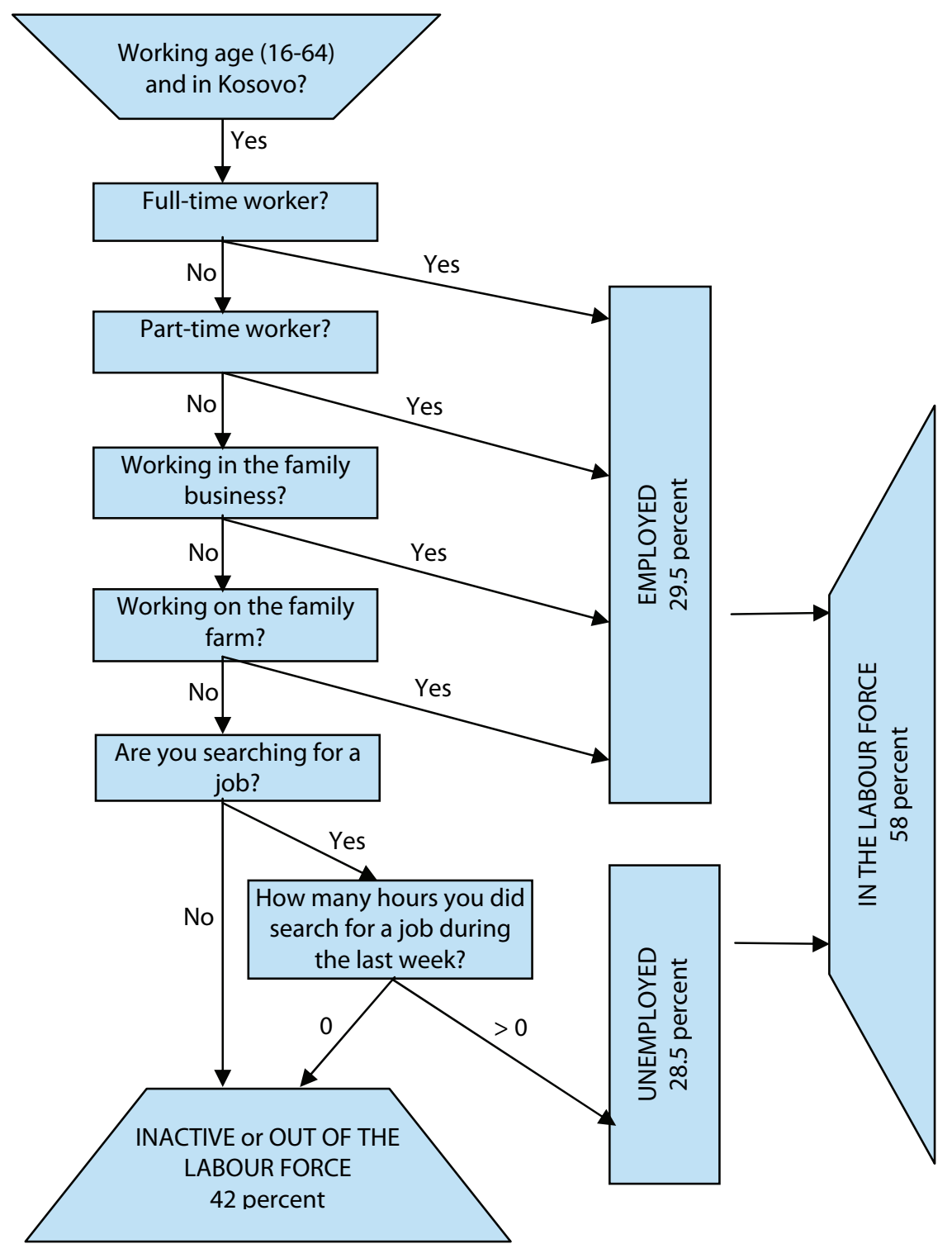

Source: Riinvest HLFS of December 2002.

Figure A1: Defining the labour force status of the working age population 


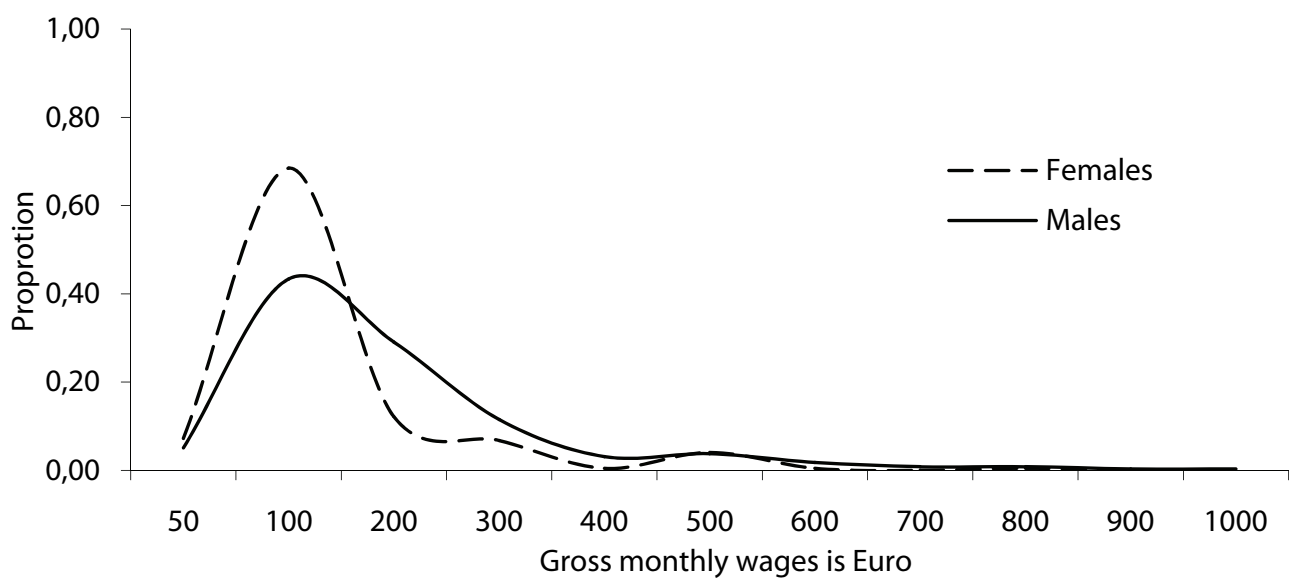

Source of data: Riinvest HLFS of December 2002.

Figure A2: The distribution of gross monthly wages for employees in Kosovo (2002)

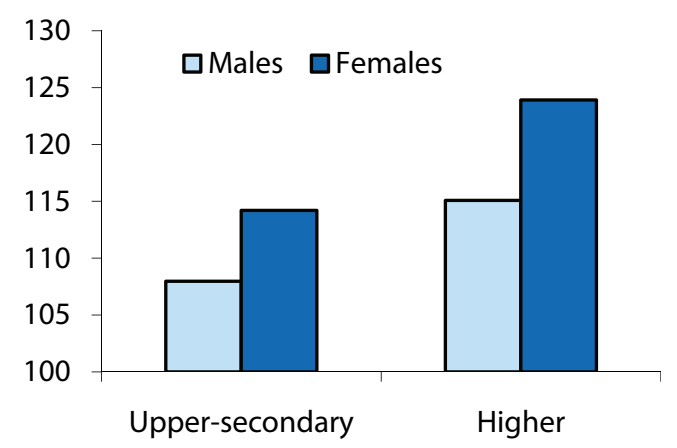

Source of data: Riinvest HLFS of December 2002.

Figure A3: Relative wages by education in Kosovo (2002)

(less than upper-secondary education $=100$ )

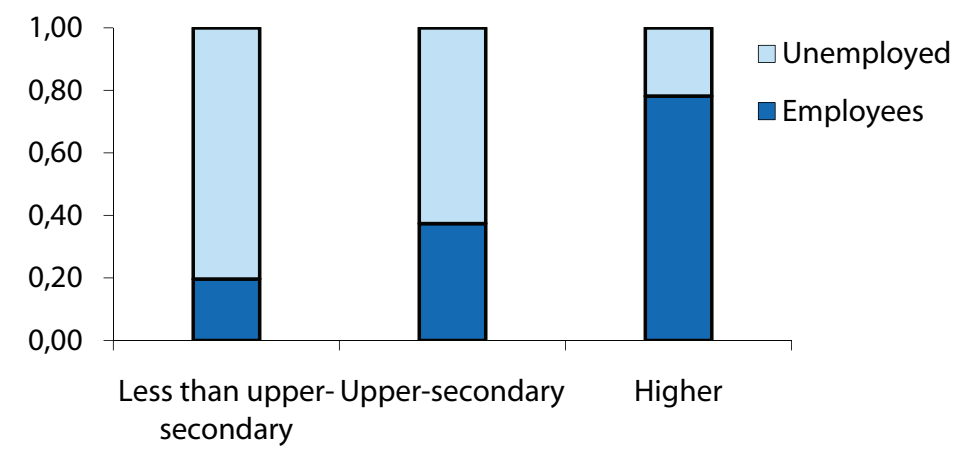

Source of data: Riinvest HLFS of December 2002.

Figure A4: The proportion of employment and unemployment by education in Kosovo (2002) 